\title{
Graduates' Orientations to Higher Education and their Retrospective Experiences of Teaching and Learning
}

\section{ABSTRACT}

In this article, we sought a relation between orientation to higher education and curricular experiences, and elucidated the nature of transformative curricular experiences. Twenty-four graduates from humanities and science degrees in the year 2000 were interviewed approximately five years later to obtain their retrospective views on the purpose of higher education, as well as their undergraduate experiences of teaching and learning. Drawing on phenomenographic principles, four orientations to higher education were generated. Four participant cases are analyzed, representing each orientation to higher education. In the 'gaining a qualification' orientation, graduates valued being told what to learn, as well as learning practical skills. For the 'preparation for a job' orientation, graduates wanted lecturers who were good at conveying information, but they also valued project work, having some autonomy over learning and practical applications. In the 'developing skills and learning how to think' orientation, graduates valued being challenged and learning in groups, but also wanted to learn professional skills. In the 'growing as an individual' orientation, graduates valued being challenged, gaining different perspectives, developing critical thinking, learning about theory, interacting with lecturers, research, and study for its own sake. Some curricular experiences transformed thinking about the purpose of higher education, including learning through discussion in small groups, authentic learning tasks including inquiry-based assignments, exercises in developing critical thinking, opportunities to interact with teachers, opportunities to develop practical skills, experiencing different cultures and personal growth through lifestyle and social experiences. Our research has implications for advising students, as well as for teachers aiming to encourage a deep approach to learning.

\section{KEYWORDS}

graduate, millennials, orientation, curriculum, experiences, higher education

\section{INTRODUCTION}

In this study we explore a possible relation between graduates' orientations to higher education and their retrospective views of their experiences of their learning environmentthe curriculum, teaching, and learning. There is little research of such a relation in studies 
of graduates, so as background we draw on the extensive literature on a similar relation amongst undergraduates.

Entwistle (2009) produced a framework describing the direct and indirect relations between students' characteristics such as their approaches to learning, prior knowledge, abilities, attitudes, work habits, and study skills and the teaching-learning environment. Research on students' orientations has focused on different aspects within this framework, yet much of it adopts common themes. Beaty, Gibbs, and Morgan (1997; see also Gibbs, Morgan, \& Taylor, 1984) described students' orientations to learning as their personal relationship with the context of their study: the complexity of experiences and characteristics that they brought to their study, their personal goals, attitudes, values, and expected outcomes. They identified four orientations to learning: vocational, academic, personal, and social.

Adopting a similar definition of learning orientation to that of Gibbs et al., (1984), Vermunt (1996) described it as "the whole domain of personal goals, intentions, attitudes, worries and doubts of students in relation to their studies” (p. 28). Relatedly, he identified four learning styles: undirected; reproduction directed; meaning directed; and, application directed. Within these four styles, learning orientations were respectively: ambivalent; certificate and self-test oriented; person oriented; and vocation oriented. Consistent relations were evident between students' processing strategies - that is their approach to learning (e.g., deep, stepwise, and concrete) — and their metacognitive regulation strategies (e.g., self, external, and lack of regulation), mental models (e.g., conceptions: construction, intake, and use), and learning orientations (Vermunt, 1998; Vermunt \& Vermetten, 2004).

In contrast, in a sociological study of American college life, Clark and Trow (1966) explored students' orientations to the overall environment. The results showed that students' views reflected a sub-culture or 'shared notion' of appropriate values and behaviors of a particular kind of college and its student body. Their four types of subculture-the collegiate, vocational, academic, and nonconformist - derived from the inter-relation of two variables: the extent to which the students engaged with ideas and how they identified with their college.

Despite the foregoing literature, there is very little research on graduates' orientations to higher education and their experiences of teaching and learning. In some earlier work at a research-intensive New Zealand university, we undertook a qualitative study exploring 24 millennial graduates' views on the purpose of higher education (Spronken-Smith, Buissink-Smith, Grigg, \& Bond, 2009). The millennials graduated in the year 2000, and their perspectives on higher education were likely shaped by the political, economic, and social context for higher education in New Zealand at that time (Buissink-Smith, Spronken-Smith, \& Grigg, 2008). For example, graduates in New Zealand at the millennium were one of the first cohorts to experience rapidly increasing fees, the abolishment of a universal student living allowance, and the introduction of a student loan system. However, similar trends were also evident internationally (see Schwartz, 1994). Indeed, Buissink-Smith et al., (2008) found many similarities between the New Zealand millennials and American millennials.

The millennials were interviewed approximately five years after graduation to allow time for them to develop their retrospective views on their experiences of their university education. Four orientations were constructed from these data: 
Table 1. Selected dimensional attributes of four orientations to higher education (from Spronken-Smith et al., 2009, p.360).

\begin{tabular}{|c|c|c|c|c|}
\hline DIMENSIONAL & A. & B. & C. & D. \\
\hline \multirow[t]{4}{*}{ ATTRIBUTE } & GAINING A & PREPARATION & DEVELOPING & GROWING \\
\hline & QUALIFICATION & FOR A JOB & SKILLS AND & \\
\hline & & & LEARNING & INDIVIDUAL \\
\hline & & & HOW TO THINK & \\
\hline $\begin{array}{l}\text { Meaning (the } \\
\text { 'what') of higher } \\
\text { education }\end{array}$ & $\begin{array}{l}\text { Outcome oriented: } \\
\text { a qualification leads } \\
\text { to a specific job }\end{array}$ & $\begin{array}{l}\text { Outcome oriented: } \\
\text { preparation for } \\
\text { employment }\end{array}$ & $\begin{array}{l}\text { More process } \\
\text { oriented: focus } \\
\text { on developing } \\
\text { intellectual skill }\end{array}$ & $\begin{array}{l}\text { Process and } \\
\text { outcome oriented: } \\
\text { personal growth } \\
\text { and development } \\
\text { leading to lifelong } \\
\text { learning }\end{array}$ \\
\hline Meaning of skill & $\begin{array}{l}\text { Related specifically } \\
\text { to the chosen field } \\
\text { - conflated with } \\
\text { knowledge learned }\end{array}$ & $\begin{array}{l}\text { General life skills: } \\
\text { time management, } \\
\text { balance, people }\end{array}$ & $\begin{array}{l}\text { Academic life } \\
\text { skills: learning how } \\
\text { to learn; applying } \\
\text { knowledge; } \\
\text { problem solving }\end{array}$ & $\begin{array}{l}\text { Academic skills: } \\
\text { analytical, critical } \\
\text { abilities, generic } \\
\text { and transferable }\end{array}$ \\
\hline $\begin{array}{l}\text { Notion of a } \\
\text { university degree }\end{array}$ & $\begin{array}{l}\text { Physical, external } \\
\text { object - piece of } \\
\text { paper, the degree } \\
\text { achieves the job }\end{array}$ & $\begin{array}{l}\text { External - but } \\
\text { related and of some } \\
\text { value to self }\end{array}$ & $\begin{array}{l}\text { Internal - } \\
\text { associated with the } \\
\text { higher education } \\
\text { experiences }\end{array}$ & $\begin{array}{l}\text { Internal - part } \\
\text { of who you are, } \\
\text { integral to the } \\
\text { person }\end{array}$ \\
\hline $\begin{array}{l}\text { Relation of higher } \\
\text { education to } \\
\text { society }\end{array}$ & $\begin{array}{l}\text { Vague and general, } \\
\text { instrumental } \\
\text { benefits }\end{array}$ & $\begin{array}{l}\text { Related to } \\
\text { the personal } \\
\text { contribution of the } \\
\text { individual }\end{array}$ & $\begin{array}{l}\text { Notion of social } \\
\text { good: a better } \\
\text { society because } \\
\text { people are more } \\
\text { educated }\end{array}$ & $\begin{array}{l}\text { Ability to question } \\
\text { societal issues and } \\
\text { bring about change }\end{array}$ \\
\hline
\end{tabular}

(A) gaining a qualification for a specific job;

(B) preparation for a job;

(C) developing life skills and learning how to think;

(D) education for its own sake: growing as an individual.

Differences in graduates' notions of a degree, and of knowledge and skills were evident across the orientations (Table 1). For example, orientations A and B were goal oriented, but whereas A focused on a single, narrow outcome or qualification for a subject-specific job, B was more flexibly focused on the provision of skills for employment rather than the acquisition of a specific job. In orientation $\mathrm{C}$, the experience continued to be associated with skills but they were interpreted more academically, while D encompassed the most flexible and wide-ranging view of higher education, associated with personal and intellectual growth and concerned with life-long learning. These aspects of dimensional variation evident in Table 1 were noted by Spronken-Smith et al. (2009) to reflect those found in other research such as that on conceptions of learning (e.g., Marton, Dall'Alba, \& Beaty, 1993) in which students' experiences ranged from superficial views reflecting external authorised notions of knowledge, to deep transformative personal change. While the authors found that the level of parental post-secondary education seemed to have a strong influence on orientations to higher education, they also suggested 
that curricular experiences had the power to change an individual's orientation to higher education.

Other researchers have identified teaching/learning environments and activities that have a significant influence on student learning. See, for example, 'signature pedagogies' (Shulman, 2005), teaching functions (Vermunt \& Vermetten, 2004), high impact educational experiences (Kuh, 2008), or a focus on engagement and authentic learning experiences (McCune, 2009).

The aims of our study were to further explore the earlier dataset to determine the nature of a possible relation between graduates' orientations to higher education and the teaching experiences they valued, and secondly, to identify whether there were particular teaching episodes that appeared to influence graduates' orientations to higher education.

\section{RESEARCH METHODS}

This research is part of the larger interview-based study of 24 millenial graduates' orientations to higher education described above (see Spronken-Smith et al., 2009). The graduates had completed an undergraduate degree in humanities or science between 1999 and 2000 at the University of Otago, New Zealand. Using interviews approximately five years after graduation, we explored participants' views of the purpose of higher education; their experiences and expectations; their most memorable curricular experiences; the ways in which their university education had equipped them for work and life; and, possible benefits to themselves and society. Interviews were recorded and transcribed verbatim, and pseudonyms were used to protect the identities of participants.

The data analysis consisted of an independent categorization by each member of the research team. During analysis, the team met to discuss the emerging categories and reach agreement about the final outcomes. Theoretically, the analysis drew on phenomenographic principles: the use of a second-order perspective, and Marton and Booth's (1997) structure of awareness (the 'what', or meaning that participants give to an experience, and 'how' they experience it). However, unlike a phenomenographic analysis, an individual's whole transcript was treated as the basic unit of analysis.

The initial analysis consisted of two phases. In the first phase, transcripts were read and reread to group transcripts according to the similarities and differences in participants' views of higher education. Each group of transcripts was treated to further in-depth analysis to unpack the meanings that participants attributed to their experience and the structural characteristics. Categories were refined and described. In the second phase, the category descriptions (from phase 1) were analyzed to determine cross-category dimensional attributes (Spronken-Smith et al., 2009, p. 354).

Participants were assigned to an orientation using their predominant view as identified by the focus and structure of their experience, the language they used, and the metaphors they invoked. Table 2 shows the main characteristics of the participants, including degree completed, parental education, and orientation. The sample for the current article comprised four graduates who were selected from the sample of 24 described above because they best represented one of the four orientations to higher education that were reported in the study. 'Barbara' was slightly unusual in her category, as she had returned to university as a mature student. Nevertheless she was selected since her interview yielded particularly rich data and captured a range of issues that were in accord with the other participants in category 'D.' All four participants were born in New Zealand. 
Table 2. Participants by age group, sex, degree, parental tertiary education, and orientation. The four participant cases used in this article are indicated with $a^{\prime *}$. (Table adapted from Spronken-Smith et al., 2009, p.355).

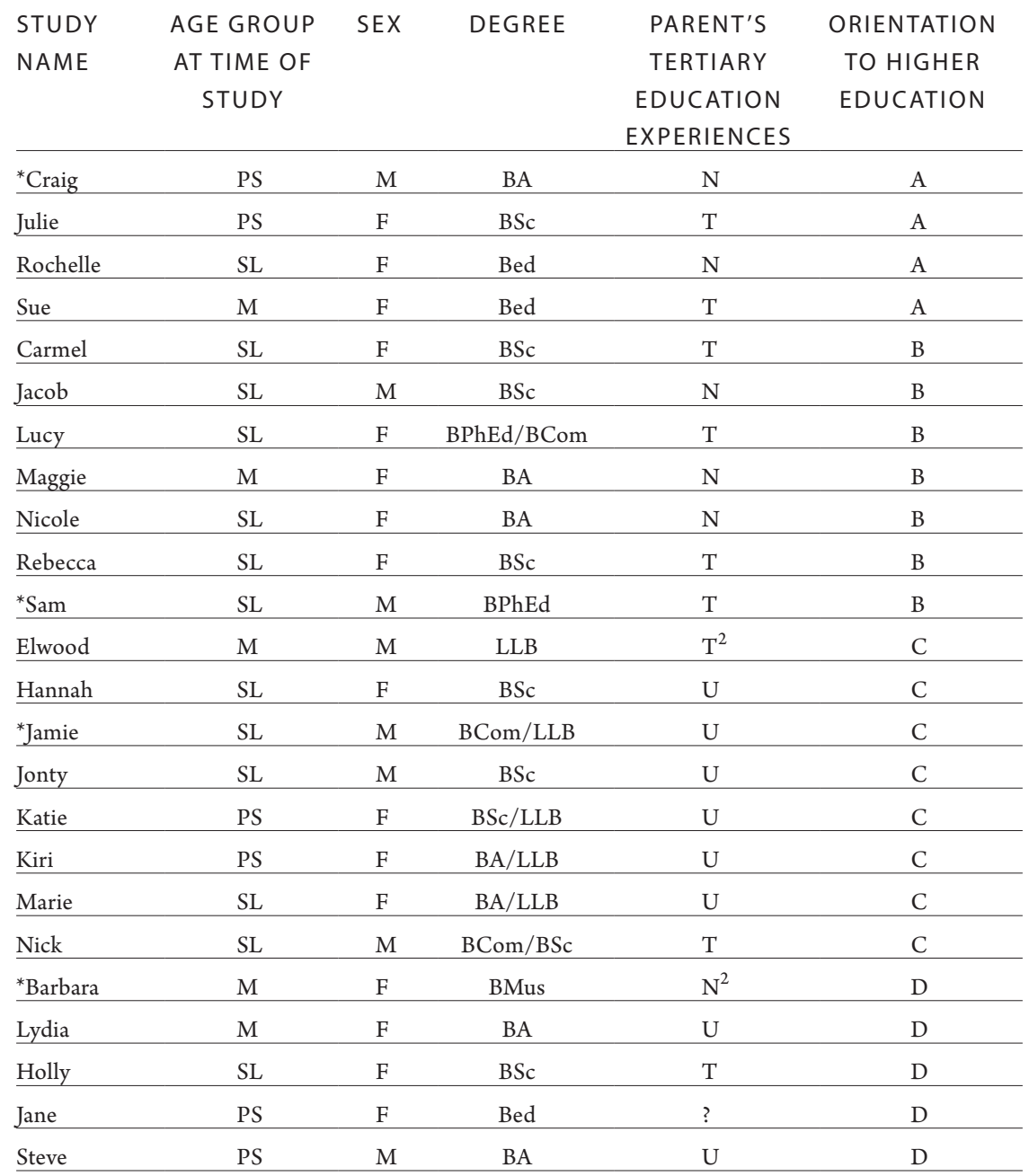

Note. Age group: $S L$ - school leaver (millennial); $P S$ - post school 1 -3 years; $M$ - mature age, $>3$ years.

Parental tertiary education experiences: $N$ - no experience of tertiary study; $T$ - tertiary education but no university qualification; $U$ - at least one parent with a university qualification.

${ }^{2}$ Both Elwood and Barbara returned to University as mature students, having completed degrees earlier in life.

Case studies were developed using each participant's interview data. The authors used narrative analysis on each transcript to explore the internal relation between participants' perceptions of the purpose of higher education, a university degree, the skill set they acquired, and their experiences of the teaching and learning context. Although participants' conceptions of learning were not directly probed, it was possible to infer their likely conceptions based on their recall of teaching and learning experiences. Using the narratives, four cases were constructed and are presented below. 


\section{RESULTS}

Each case includes a brief biography, a narrative to exemplify the relation between the individual's orientation to higher education and their experiences of teaching and learning, and some commentary.

\section{A. Gaining a qualification-teaching as being told information}

For Craig, the purpose of higher education was to gain a qualification. He described himself as a high school dropout, opting to leave school early, who had held a series of short-term jobs. He then enrolled at university, majoring in Design with a minor in Classics. He was the first in his family to complete a university degree. Following graduation, Craig worked in a cinema and as a manager at a small bookshop. In the narrative below, Craig compares his experiences of teaching in Design and Classics:

I loved the Classics papers, all of them - they were really fascinating and interesting. The lecturers were very good in imparting information. Whereas the Design lecturer was terrible.... I found that I just wasn't getting the information I needed to pass my courses.... And that kind of made me angry because I'm thinking: I'm paying how many hundreds of dollars for this paper? I found the Design tutorial boring because they just sat around and talked, whereas Classics I'd go along and listen to these tutors and they knew it all, so they could tell you what possibly Homer was thinking or you know what were the reasoning behind .... I think it was more reinforcing what we'd learned in the lectures ourselves.

In Design they'd do some really stupid things. One of them was a project on defining what a book was. And I went to a lot of trouble to create an actual book - even got gold writing on the top and I had to glue all the pages together.... And a friend of mine, said "oh man, I forgot about that, I should do it now." So he got like a paving stone, he got a gold plaque printed out that said 'Book' on it and he got a whole lot of plaster and put it on top of foil to make it look kind of like a brain. And he got a higher mark than me. And I couldn't believe it. But maybe they were looking for something more abstract, which I wasn't really leaning towards, I didn't like abstract stuff, I liked more realized pieces.

I think basically a degree should just be physical evidence that you've done these courses and you've obtained this knowledge and you'd be a useful person to employ.

Given his orientation and his focus on the cost of his university education, Craig valued teaching that told him what he needed to know to pass the course and gain a qualification. He was very goal-oriented in his approach to studying. In Classics, this need was satisfied; whereas, in Design, he felt his teachers were not giving him the necessary knowledge to pass the course. Craig opted not to attend Design tutorials because they just "sat around and talked." He also resented a Design assignment that encouraged abstract thinking, preferring instead more realized pieces. Craig was unaware of the range of skills that he had likely acquired. However, he recognized that his Classics study had 
led to an unexpected passion and a personal enthusiasm in the topic, and he hoped that his Design degree would open up business opportunities.

\section{B. Preparation for a job-teaching as being given information and developing academic and social skills}

Sam decided to go to university because that was his school cohort culture (neither of his parents went to university, but one brother did). Sam did not know what he wanted to study, but because he enjoyed physical education, he enrolled in that as well as taking some subjects in Geography and Psychology. He learnt the ropes of how to pass ("C's a degree") and completed a Physical Education degree (with a minor in Marketing). He then did a year at Teachers College but became disenchanted with teaching as a career, so he went back to Otago and completed a BCom degree, five years after first enrolling. At graduation, he had a $\$ 65,000$ loan and "3 bits of paper to show for it." He taught English in South Korea to help pay off his loan. Then he returned to Christchurch, applied for 80 jobs in three months unsuccessfully (and was on the benefit), and decided to do some relief teaching. Soon after, he had three job offers. He initially worked in customer service for outdoor equipment, then as a sales representative for a brewery, and then at a footwear wholesaler and distributor. At the time of interview, he had been there for about 18 months:

In terms of skills, my education has taught me about researching as far as finding information or even having the ability and the nouse to make conversations. So by having projects that made you research a book and actually read it and then, make a call on it - is that their thought, was it true, what is it? I have got a few mates who will read a magazine and they'll believe it whereas I'll read it and I'll be critical of it, going well who said it? However, there should be more emphasis on the practical - actually doing it.

Compared to a polytechnic qualification, I guess the degree is more indepth research and you're dealing with far more complicated and detailed analysis of specific things like you learn the entire body's anatomy. So I mean, of course you're going to have added value. I liked Phys Ed. I got a degree in something that I enjoyed as a topic. But I found the topic was far more in depth and broad and it wasn't really my sort of scene. But the skills I got from that, and the people I met, have allowed me to be able to cross over into other things.

One of my best papers was an introductory Accounting paper. The lecturer was good because he used examples all the time of situations that you could relate to. I think the lecturer is the one that makes the course, because it's whether you want to go and see them and listen to information that's conveyed. And another guy, in Marketing, sort of opened my eyes up as far as, as what university was meant to be doing and what it was doing. He had been a businessman and he was just coming back to further his education as well as lecture. So I always respected guys who had been out and done it versus people who just talked about it. 
When Sam came to university, he initially thought that the purpose of a higher education was to get a "better paid job." At the time of interview, he was frustrated since he had decided he really wanted to be a personal fitness trainer, and this required only a six week course at a polytechnic. Yet he had invested five years in higher education and had accrued a substantial debt in the process. As he said, "the educational side [of university] is for you to generate money for yourself. The social side is for happiness." At the time of interview, Sam felt his higher education had not yet yielded the monetary benefits. However, Sam recognized that his curricular and learning experiences had expanded his ideas about the purpose and value of a degree. He thought that his university degrees had added value over a polytechnic qualification, but questioned whether he really needed this depth of knowledge. However, he was aware that the academic and social skills he had acquired would be useful in the workplace. He valued learning tasks that helped him develop skills in evaluation and critical thinking. He liked lecturers who had had real world experience and who used examples to which he could relate. However, there was still a sense of the lecturer being there to convey information.

\section{Developing skills and learning how to think-teaching through discussion and projects}

Jamie had strong family ties to the University of Otago and studied Law, spending his first year in a residential college. He met a broad range of people and, as he said, "got the full university experience." After graduation, he travelled for three months and then worked at a Wellington law firm for four years. He then worked as an associate in investment banking for a financial institution and had been working there about four months at the time of interview. He saw this as quite a different career path but with some crossover with law:

I recall a memorable lecturer who is quite a famous guy at Otago and he sort of thinks at a different level than just about anyone else at the university! But it was interesting because by the end of the course, if you actually put quite a bit of time and hard work in and tried to understand what he was saying, his thinking wasn't ridiculous or strange.

Another lecturer used to have focus groups, and then we'd actually get comments back to him or he would come in and we would discuss it further. It wasn't so much writing down or doing test after test. It was actually giving direction and learn the stuff so you could actually discuss it, which was quite good.

We did a few group work projects in Finance and they were important. It's where you get the skills of learning how to work with a team. There should be more in the various subjects that we did in Law because you could see in Marketing (where they did a lot of group work), the benefits they got out of the group projects. And working with a group was beneficial and in the work place, you're always working in a team.

University education doesn't prepare you for a specific job - as you still have to learn the specific job skills when you get there. University teaches you how to research, the way to write and formulate things, how to work 
hard and concentrate for long periods of time when you need to. And then, on the other side of things, is the lifestyle, experience, communication and networking, which are huge benefits in the workplace and which are, I think the key to being educated at Otago. As soon as you get a job you've got to learn new skills fairly quickly and you're used to that from doing it at university is-since it is not so much spoon-fed. It's a more open way of doing it at university-you're a little bit more independent and you can learn in your own way.

Jamie's recollections of memorable moments of teaching and learning at Otago involved being intellectually challenged, learning through discussion with peers, and group work on projects. He valued developing academic, transferrable, social, and life skills. His responses indicated that he was likely a strategic learner, as evidenced by comments such as "you study how to pass." Jamie thought the purpose of university was twofold: "developing professional skills to enable you to advance in a particular career" and "learning how to learn." So, alongside his personal growth, he valued gaining credentials and experiences that would stand him in good stead for the workplace.

\section{Education for its own sake: growing as an individual-teaching as transforming thinking}

Barbara first gained a BA in English and History in late 1960s. After marriage, she trained and worked as a primary school teacher. Later in her life, she moved to Dunedin, and when she was unable to obtain a teaching job, she returned to university (at Otago) to study Music. Since graduating with her degree in 2000, she has done some relief teaching and had a mix of short-term jobs. At the time of interview, she was back at Otago University studying Community and Family Studies and hoping to continue with postgraduate study:

What I'd never suspected before was how satisfying and how rewarding it can be just to study something. I think the purpose of university is to show people how studying can actually be rewarding in itself and for its ownfor its own reasons, not for any particular job. Study meant that I could be more receptive to other points of view rather than just my own and I think that this is totally and utterly crucial for the future of the world that people can actually think in other ways from what they were brought up in. To let themselves be inducted into another person's world and actually see the world from their point of view, to actually have the agility of mind to be able to do that - to me that was just wonderful.

In terms of learning, for me theory is all important at the university. Translating that theory into practice is a secondary consideration. I can see that the more I find out the less I know. The more there is to find out. But I can see what the lecturers are doing and they're all engaged in research that is actually going to help everybody. Not just them, not just the university, but the whole world.

When I got back to University I thought I would do a music degree as it might help me to get a job as a secondary school music teacher. But I no- 
ticed that the main thrust of the course was not how you can use this in the community or how you could use this in the school, it was: this is what we're studying, this is what we've found out, and these are other areas that need to be explored. And that was very interesting because for easily 30 years I had actually been focusing on: how can I use this at school? But this is not the focus of the university. In Music, our lecturers let us in on their research. For example, we were given an assignment in Year Three in Ethnomusicology. We had to pick an area of world music that we were interested in and choose a concrete example of a piece of music, analyze that music and write an essay on how we thought the music was constructed, what sort of purpose did it fulfill for the people that were performing the music. I chose the Solomon Islands and it sort of drew me in - it really did. And what use would that be to me in the practical sense here in Dunedin? Virtually nothing. But it was absolutely fascinating.

Barbara's views on the purpose of higher education evolved while studying Music. Initially she had returned to university to study Music so that it could help her find a job as a music teacher. However, as shown above, she came to perceive higher education as not being about credentialism, but more about education for its own sake. A third-year assignment in Ethnomusicology was a transformative learning experience. This assignment involved her researching a topic of interest, which she became fascinated in. Her study generated passion and enthusiasm, and she demonstrated key elements of being a life-long learner. She valued learning through discussion so she could gain other perspectives. She liked being challenged by lecturers and thought that universities should be more focused on research and theory compared to a more vocational and practical emphasis at polytechnics. Barbara's commentary indicated she had had a transformative learning experience at university, and she was clearly taking a deep approach to learning. She valued aspects of teaching such as those which broadened her views, challenged her thinking, and gave her the opportunity to undertake research.

\section{DISCUSSION}

Our study has focused on the retrospective views of millennial graduates on their higher education experiences. We first discuss the relation between orientation to higher education and valued curricular experiences, and then consider curricular experiences that can have a transformative effect on learning and thus on a student's orientation to higher education. Finally we consider limitations of the study.

\section{Orientation to higher education and valued curricular experiences}

The constructed cases illustrate a close internal link between a participant's orientation to higher education and the curricular experiences they value. Table 3 summarizes aspects of teaching and learning experiences amongst the different orientations. There is a clear shift in perspectives about valued curricular experiences from orientation A through to $\mathrm{D}$. Those holding orientation A were very focused on gaining the piece of paperphysical evidence of having studied — and valued curricular experiences that helped them gain the necessary knowledge to pass their exams. For example, Craig thought the role of teachers was to impart the knowledge necessary to pass, and he was frustrated if his lecturers were not giving him sufficient knowledge. He liked being told what to learn and 
Table 3. Comparison of perspectives on curricular experiences between the different orientations.

\begin{tabular}{|c|c|c|c|c|}
\hline & ORIENTATION A: & ORIENTATION B: & ORIENTATION C: & ORIENTATION D: \\
\hline & QUALIFICATION & FOR A JOB & SKILLS AND & ITS OWN SAKE - \\
\hline & FOR A SPECIFIC & & LEARNING HOW & GROWING AS AN \\
\hline & JOB & & TO THINK & INDIVIDUAL \\
\hline $\begin{array}{l}\text { Role of } \\
\text { teaching }\end{array}$ & $\begin{array}{l}\text { To impart the } \\
\text { knowledge necessary } \\
\text { to pass exams }\end{array}$ & $\begin{array}{l}\text { To convey knowl- } \\
\text { edge but also to } \\
\text { develop academic } \\
\text { and social skills }\end{array}$ & $\begin{array}{l}\text { To challenge, } \\
\text { to encourage } \\
\text { discussion and } \\
\text { debate, to teach } \\
\text { research skills }\end{array}$ & $\begin{array}{l}\text { To enthuse and } \\
\text { challenge, to transform } \\
\text { thinking. To foster } \\
\text { academic endeavor. }\end{array}$ \\
\hline $\begin{array}{l}\text { Valued } \\
\text { curricular } \\
\text { experiences }\end{array}$ & $\begin{array}{l}\text { Being told what to } \\
\text { learn; } \\
\text { learning practical } \\
\text { skills }\end{array}$ & $\begin{array}{l}\text { Lecturers good } \\
\text { at conveying } \\
\text { information; project } \\
\text { work; having } \\
\text { some autonomy } \\
\text { over learning; } \\
\text { more practical } \\
\text { applications }\end{array}$ & $\begin{array}{l}\text { Being challenged, } \\
\text { learning through } \\
\text { discussion, group } \\
\text { work, learning base } \\
\text { professional skills }\end{array}$ & $\begin{array}{l}\text { Being challenged; } \\
\text { gaining different } \\
\text { perspectives; developing } \\
\text { critical thinking; } \\
\text { learning about theory; } \\
\text { interaction with } \\
\text { lecturers; research; } \\
\text { study for its own sake }\end{array}$ \\
\hline $\begin{array}{l}\text { Valued } \\
\text { teaching } \\
\text { methods }\end{array}$ & $\begin{array}{l}\text { Well-structured } \\
\text { lectures; } \\
\text { practical work }\end{array}$ & $\begin{array}{l}\text { Learning through } \\
\text { doing; practical } \\
\text { sessions; lectures } \\
\text { with examples of } \\
\text { personal relevance }\end{array}$ & $\begin{array}{l}\text { Inspiring lectures, } \\
\text { group project work }\end{array}$ & $\begin{array}{l}\text { Group discussions; } \\
\text { research-based } \\
\text { teaching; inquiry-based } \\
\text { assignments }\end{array}$ \\
\hline $\begin{array}{l}\text { Inferred } \\
\text { approach to } \\
\text { learning }\end{array}$ & Surface; reproductive & $\begin{array}{l}\text { Surface; learning as } \\
\text { acquiring facts and } \\
\text { procedures }\end{array}$ & Strategic; deep & Deep; transformative \\
\hline
\end{tabular}

valued learning practical skills that would be of use in a future workplace. His inferred approach to learning was a surface, reproductive approach.

Sam, an example of those holding orientation B, similarly liked learning practical skills (Table 3), as he thought a university education was about preparation for a job. However, he appreciated that the skills he was gaining were transferrable into many jobs, not one specifically related to his degree (unlike Craig). Similar to Craig, Sam thought the role of teaching was to convey information, but Sam also thought teaching should develop academic and social skills. As with Craig, Sam did not really value learning theoretical aspects. However, Sam was keen to gain skills through team and project work that would be of value in the workplace. Sam's approach to learning appears to be more sophisticated than that of Craig, but still he is generally taking a surface approach to learning.

The facets of teaching and learning that were valued showed a qualitative shift from orientation $\mathrm{B}$ to $\mathrm{C}$ and $\mathrm{D}$. Jamie, an example of orientation $\mathrm{C}$, thought the purpose of university was both to gain a credential and become a lifelong learner. Thus although he still valued gaining base professional skills, he also liked to be challenged and enjoyed learning through discussion with peers. Similarly, Barbara (orientation D) enjoyed being challenged and learning through discussion. However, she was not focused on credentialism, but rather on education for its own sake. For her, teaching was to transform thinking and foster academic endeavor. She loved the theoretical aspects and relished 
opportunities to undertake research. Unlike the others, she was not interested in developing practical, workplace skills. Moreover, she had clearly developed an enthusiasm and passion for her study. Whilst Jamie demonstrated aspects of taking a strategic approach to learning, he was clearly taking a deep approach to his study. Similarly, Barbara seemed to be taking a deep approach to learning, and indeed displayed characteristics in line with the sixth conception identified by Marton et al. (1993) of learning involving changing as a person.

Our research demonstrates that the post-graduation memories of teaching and learning at university relate closely to the individual's orientation towards higher education. Moreover, the research shows that, for some people (such as Craig), learning approaches can be consistent over time despite apparent attempts to encourage deep approaches to learning. It has been widely reported that students' approaches to learning are relational since the perception that students have of their learning environment can affect the learning approach they adopt for a particular task. Also, as Trigwell, Prosser, and Waterhouse (1999) reported, there is a strong alignment between teachers' approaches to teaching and their students' approaches to learning.

Some graduates in this study, however, recalled numerous occasions when they either outrightly rejected (e.g., not attending or participating in small group discussions) or simply did not understand approaches to encourage a deeper approach to learning (e.g., Craig's frustration at the book assignment in Design). This supports the idea put forward by Ramsden (2003) that it is more difficult to encourage constructive and deep approaches to learning, especially when there is a reproductive orientation to learning.

\section{Transformative curricular experiences}

Our research found that certain curricular experiences can help shift orientations of higher education, even for some students with a reproductive orientation to learning. For example, Sam initially had a very instrumental view of higher education and, at the outset, was happy to obtain the bare minimum to pass ("C's a degree"). His learning experiences, particularly around developing critical thinking and research skills, instilled in him the recognition that he had a broad academic and social set of skills that would stand in him good stead for a range of jobs. Barbara's transformative learning occurred in an open discovery-oriented inquiry-based ${ }^{1}$ research assignment. During her study for this assignment, she became immersed in her research and realized the centrality of research to higher education.

This article has, by necessity of brevity, focused on the experiences of four out of 24 interviewees. However, considering the other 20 interviewees whose data are not presented here, transformative learning experiences were identified as including:

- Learning through discussion - hearing others' perspectives was thought to broaden horizons and challenge one's thinking.

- Authentic learning tasks - the opportunity to engage in inquiry-based research projects or on tasks relevant to potential future workplaces.

- The development of critical thinking skills - for example through assignments that required one to critique work.

- Opportunities to interact with teachers - quality learning environments such as tutorials, field trips and laboratories, where relationships can be built with teachers. 
- Opportunities to develop practical skills - nearly three quarters of those interviewed held orientations A, B, or C - all of which involved credentialism. Certainly, for these people, it was important that their university education should help them acquire skills suitable for the workplace.

- Experiencing different cultures - exposure to different cultures, both in terms of the culture of campus life, and by meeting people from different social and cultural mixes was identified as being a very formative time.

- Lifestyle and social experiences - for most of those interviewed, their time at Otago had been one of immense personal growth and often the social side of university was the most memorable. Even if the graduates had experienced some unsatisfactory curricular experiences (as had a couple), their lifestyle and social experiences more than made up for this. Thus, there was an overwhelming sense of graduating with an 'Otago Package' - a strong Otago identity, a positive experience with positive educational outcomes and a social experience that outweighed any short-comings in the curriculum.

The transformative learning experiences detailed by the four cases and described in the larger interview cohort accord well with past research (e.g., Biggs \& Tang, 2007; Entwistle \& Peterson, 2004; Kuh, 2008; Prosser \& Trigwell, 1999; Ramsden, 2003). For example, Kuh (2008) identified ten high-impact educational practices, five of which were evident in our study: collaborative assignments and projects, undergraduate research, learning communities, diversity and global learning, and capstone courses and projects.

\section{Study limitations}

Our study has relied on participants to recollect experiences of their university education. Thus, it is possible that their recollections may be inaccurate or biased. Moreover, the findings pertain to graduates from one university in New Zealand at a particular time. While we recognize that the millennials may have some special characteristics (e.g., see Buissink-Smith et al., 2008; Howe \& Strauss, 2000), we believe that both the nature of the relation between orientation to higher education and curricular experiences, and perspectives on transformative curricular experiences are likely relevant to today's graduates. However, further research is required to see if such observations hold true in other higher education contexts.

\section{CONCLUSIONS AND IMPLICATIONS}

Our study aimed to determine if there was a relation between orientation to higher education and curricular experiences, as well as elucidating the nature of transformative curricular experiences. A close internal relation was found between an individual's orientation to higher education and what they valued in terms of their formative learning experiences. Graduates with a very instrumental view of higher education valued being told what to learn and liked teachers giving them the knowledge necessary to pass, characteristics of a surface reproductive approach to learning. In contrast, graduates who viewed the purpose of higher education as education for its own sake, without any vocational focus, valued being challenged, enjoyed discussion and debate, and relished opportunities to learn through research projects - characteristics of a deep, transformative approach to learning. Whilst some graduates had changed their orientations to higher education 
through transformative learning experiences, some graduates with reproductive learning approaches resisted attempts to engage them more deeply in their learning. Transformative learning experiences included learning through discussion in small groups, authentic learning tasks including inquiry-based assignments, exercises in developing critical thinking, opportunities to interact with teachers in smaller class settings, opportunities to develop practical skills, experiences with different cultures and personal growth through lifestyle and social experiences.

Entwistle (2009) talks of the "inner logic" of subject and pedagogy that helps provide an explanatory framework for understanding relations (p. 3). Our study supports and perhaps extends the notion of "inner logic" beyond students' immediate experiences to graduates' orientations and their retrospective views of their experiences in the undergraduate curriculum.

Our findings have several implications for teachers. Of critical importance in terms of likely approach to learning is the individual's orientation to higher education. As SpronkenSmith et al. (2009) showed, an individual's orientation to higher education is strongly influenced by parental post-secondary education. In particular, first-in-family students were more likely to hold more instrumental views of higher education. Thus it is important that through student advising, as well as in classroom settings, the purpose of higher education is explored with students. Accordingly, if teachers are attempting to encourage a deep/constructive approach to learning, as well as using appropriate teaching, learning, and assessment activities, they should also address factors that may be underlying the orientations to learning such as orientations to higher education. Thus they should discuss the aims and purpose of higher education, and how their course is aligned with these. This may help students holding orientation A or B see the value of particular classroom techniques such as learning through discussion, and why theory is important.

Close attention should be paid to elements of the undergraduate curriculum to ensure inclusion of tasks which have been identified as having a transformative influence on learning. These include smaller group settings that allow discussion and debate, quality teaching situations with excellent staff to student ratios, authentic tasks such as research projects that tackle real-world problems, opportunities to critique others' research, development of transferable skills such as oral communication, time management, and teamwork (group project work provides a forum to develop these skills).

Moreover, a strong signal from our study is that the development of workplace skills is desirable. In a user-pays system such as that in New Zealand universities, it is clear that most graduates are not studying solely for personal growth, but also to gain a credential. Thus, such students are seeking opportunities to develop knowledge and skills of relevance to future work. However, it is not sufficient simply to include the learning tasks described above without discussing with the students why they are in the curriculum. Students need to be made aware of the range of skills the curriculum is aiming to develop so that they can see the value in particular learning situations. It was apparent that some of the graduates failed to see the importance or relevance of such things as tutorials or discussion groups.

We would like to extend our study by investigating our participants' perceptions of the appropriateness/effectiveness of their learning orientations at university, and their subsequent appropriateness/effectiveness in their work environments. Whether our participants maintained the same orientation to learning since the time of interview, and 
their perceptions of any work-related factors that influenced their orientation to learning, is also worthy of further study. Future research could track students in transition to university and during their study, as well as with time after graduation to explore how orientations to learning and higher education may change over time, and the major influences upon these changes.

\section{ACKNOWLEDGEMENTS}

This research was funded by two University of Otago 'Research into Teaching' grants.

Dr. Rachel Spronken-Smith is a Professor of Higher Education and Geography and Dean of the Graduate Research School at the University of Otago.

Dr. Nell Smith, formerly a Research Fellow in Higher Education at the University of Otago, is now a Senior Lecturer in the Centre for Learning and Teaching at AUT University.

Dr. Carol Bond is an Honorary Senior Lecturer in the Higher Education Development Centre at the University of Otago.

Dr Gabrielle Grigg, formerly a Research Fellow in Higher Education at the University of Otago, is Research Higher Degree Administrator at the University of Melbourne.

\section{NOTES}

1. Different types of inquiry-based learning are described in Spronken-Smith and Walker (2010).

\section{REFERENCES}

Beaty, E., Gibbs, G., \& Morgan, A. (1997). Learning orientations and study contracts. In F. Marton, D. Hounsell, \& N. Entwsitle (Eds.), The experience of learning. Implications for teaching and studying in higher education (pp.72-86). Edinburgh, Scotland: Scottish Academic Press.

Biggs, J., \& Tang, C. (2007). Teaching for quality learning at university (3 $3^{\text {rd }}$ Ed.). Berkshire, England : Society for Research into Higher Education \& Open University Press.

Buissink-Smith, N., Spronken-Smith, R.A., \& Grigg, G. (2008). Understanding the millennial generation. Can the literature go Down Under? New Zealand Journal of Educational Studies, 43(1), 127-145.

Clark, B.R., \& Trow, M. (1966). The organizational context. In T.M. Newcomb \& E.K. Wilson (Eds.), College peer groups. Problems and prospects for research (pp. 17-70). Chicago, IL: Aldine Publishing Company.

Entwistle, N. (2009). Teaching for understanding at university. Deep approaches and distinctive ways of thinking. Basingstoke, England: Palgrave Macmillan.

Entwistle, N.J., \& Petersen, E.R. (2004). Conceptions of learning and knowledge in higher education: Relationships with study behaviour and influences of learning environments. International Journal of Educational Research, 41, 407-428.

Gibbs, G., Morgan, A., \& Taylor, E. (1984). The world of the learner. In F. Marton, D. Hounsell, \& N. Entwistle (Eds.), The experience of learning (pp. 165-188). Edinburgh, Scotland: Scottish Academic Press.

Howe, N., \& Strauss, W. (2000). Millennials rising: The next generation. New York, NY: Vintage. 
Kuh, G. (2008). High-impact educational practices: What they are, who has access to them, and why they matter. Washington, DC: Association of American Colleges and Universities.

Marton, F., \& Booth, S. (1997). Learning and awareness. Hillsdale, NJ: Lawrence Erlbaum Associates.

Marton, F., Dall'Alba, G., \& Beaty, E. (1993). Conceptions of learning. International Journal of Educational Research, 19, 277-300.

McCune, V. (2009). Final year biosciences students' willingness to engage: Teaching-learning environments, authentic learning experiences and identities. Studies in Higher Education, 34(3), 347-361.

Prosser, M., \& Trigwell, K. (1999). Understanding learning and teaching. The experience in higher education. Berkshire, England: The Society for Research into Higher Education and Open University Press.

Ramsden, P. (2003). Learning to teach in higher education. London, England: Routledge/Falmer.

Schwartz, H. (1994). Small states in big trouble. State reorganisation in Australia, Denmark, New Zealand and Sweden in the 1980s. World Politics, 46, 527-555.

Shulman, L.S. (2005). Signature pedagogies in the professions. Daedalus, Summer, 52-59.

Spronken-Smith, R.A., Buissink-Smith, N., Grigg, G., \& Bond, C. (2009). Millennium graduates orientations to higher education. College Student Journal, 43(2), 352-365.

Spronken-Smith, R., \& Walker, R. (2010). Can inquiry-based learning strengthen the links between teaching and disciplinary research? Studies in Higher Education, 35, 723-740.

Trigwell, K., Prosser, M., \& Waterhouse, F. (1999). Relations between teachers' approaches to teaching and students' approaches to learning. Higher Education, 37, 57-70.

Vermunt, J.D. (1996). Metacognitive, cognitive and affective aspects of learning styles and strategies: A phenomenographic analysis. Higher Education, 31(1), 1-21.

Vermunt, J.D. (1998). The regulation of constructive learning processes. British Journal of Educational Psychology, 68, 149-171.

Vermunt, J.D., \& Vermetten, Y. J. (2004). Patterns of student learning: Relationships between learning strategies, conceptions of learning and learning orientations. Educational Psychology Review, 16, 359-384. 